\title{
Expressions of Appreciation
}

I cannot express the depth of my gratitude to those of you who are carrying on rith this publication. Having been so close to the "Blue Jay" from the moment of its "birth pains", shall we say, I feel safe in stating that I alone kno what it meant to ifs. Priestly and the amount of work and thought she put into it. If for no other reason than that, and there are numerous reasons for its continuation, I can only look on it as a "ronument" to her and her love for llature's finest, as vell as the increased love of such things that broadened through the "Blue Jay" for all those who read it.

As all readers knor, the "Blue Jay" was first published as a bulletin for the benefit of the members of the Yorkton Natural History Society. The interest taken in it and its circulation grorth ras a source of pleasant surprise to irs. Priestly. Naturally I felt a great deal of reflected pride in this myself.

From the time that its growth seemed a positive fact it was lírs. Priestly's belief that it should become the official organ of a society of wider scope. There vas no provincial organization and the formation of one seemed unlikely, hence her approach to the Provincial Yruseum for joint sponsorship in September, 1945. That her one-time dream is about to become realized is a great source of satisfaction to our children and myself.

$$
\begin{array}{r}
\text { Robt.J. (Bob) Priestly, } \\
\text { Reeina. }
\end{array}
$$

With the inauguration of the Saskatcheran Natural History Society and its assumption of the publication of the BLUE JAY, the members of the Yorkton Natural History Society extend best wishes to the new Society and pledge their support. Yorkton deservedly enjoys a measure of pride in the efforts of publishing the BLUE JAY in the past, but passes on the editorship with confidence to Ir. I. T. Carmichael with the desire that he should perpetuate the vital spirit and interest in nature possessed by Mr. Cliff Shaw and the late Iirs. I. M. Priestly.

\author{
Clive Tallant, \\ Vice-President, \\ Yorkton Natural History Society.
}

In conservation alone, I feel as if little voices are calling to you, tho seem to understand their plicht. itany are seriously threatened with extermination and may be lost forever. Let us not be known as a generation of ruthless destructiveness but instead do everything in our power to save our beautiful native life. Through the medium of the BLJE JAY a great opportunity is given to you to present the true facts and appeal for justice. I am vitally concerned over the fate of the flora and fauna of our Prairies. However, I have great faith in humanity, and when the true facts are known by all, the public ill cease destroying and start conserving. 